\title{
Acute Stress Decreases but Chronic Stress Increases Myocardial Sensitivity to Ischemic Injury in Rodents
}

\author{
Eric D. Eisenmann ${ }^{1}$, Boyd R. Rorabaugh ${ }^{2}$ and Phillip R. Zoladz ${ }^{1 *}$ \\ 'Department of Psychology, Sociology and Criminal Justice, Ohio Northern University, Ada, OH, USA, ${ }^{2}$ Department of \\ Pharmaceutical and Biomedical Sciences, Ohio Northern University, Ada, OH, USA
}

Cardiovascular disease (CVD) is the largest cause of mortality worldwide, and stress is a significant contributor to the development of CVD. The relationship between acute and chronic stress and CVD is well evidenced. Acute stress can lead to arrhythmias and ischemic injury. However, recent evidence in rodent models suggests that acute stress can decrease sensitivity to myocardial ischemia-reperfusion injury (IRI). Conversely, chronic stress is arrhythmogenic and increases sensitivity to myocardial IRI. Few studies have examined the impact of validated animal models of stress-related psychological disorders on the ischemic heart. This review examines the work that has been completed using rat models to study the effects of stress on myocardial sensitivity to ischemic injury. Utilization of animal models of stress-related psychological disorders is critical in the prevention and treatment of cardiovascular disorders in patients experiencing stress-related psychiatric conditions.

Keywords: stress, cardiovascular, ischemia, anxiety, PTSD, rodent

\section{INTRODUCTION}

The goal of this review is to analyze recent literature utilizing rodent models to examine the impact of psychological stress on sensitivity to myocardial ischemia-reperfusion injury (IRI) in the context of the well-established relationship between stress, myocardial ischemic injury, and cardiovascular disease (CVD). Stress is a general adaptive response provoked by stimuli that disrupt homeostasis $(1,2)$. The stress response activates systems responsible for mobilizing the energy and resources necessary to overcome this homeostatic disturbance. The main systems activated include the hypothalamicpituitary-adrenal (HPA) axis and the sympathetic adrenomedullary (SAM) system $(3,4)$. Stress results in the release of corticotropin-releasing hormone (CRH) from the paraventricular nucleus, which then causes the release of adrenocorticotropic hormone (ACTH) from the anterior pituitary. ACTH acts on the adrenal cortex to synthesize and secrete the glucocorticoid (GC) hormone cortisol (in humans) or corticosterone (in rodents) $(3,5)$. The hypothalamus also activates the adrenal medulla via the sympathetic nervous system (SNS), which results in the release of the catecholamines epinephrine and norepinephrine. ACTH, CRH, and GCs provide the negative feedback necessary to dampen the stress response and return the body to homeostasis $(4,6)$. Cessation of the stress response is important to prevent damage associated with a prolonged stress response $(3,4,7)$. Acute stress generally results in an adaptive response to homeostatic changes; the stress response becomes 
harmful if it persists chronically (8-11). Thus, stress research can be roughly divided into research examining the effects of acute or chronic stress $(3,4,7,9-11)$.

Physical or psychological stressors can result in the stress response. Physical stressors disrupt the internal or external environment of an organism and include stimuli such as anoxia, heat, cold, or physical strain (exercise or injury). Psychological stressors are stimuli that affect emotion and result in fear, anxiety, or frustration (8-11). As previously discussed, anything disrupting homeostasis can be a stressor; however, this review focuses on stressors with a psychological component.

Chronic stress can have damaging effects on the whole organism (4). Stress precipitates psychiatric disease, such as depression and post-traumatic stress disorder (PTSD), and worsens physical health outcomes, such as CVD $(12,13)$. Furthermore, patients with psychiatric disorders have a higher incidence of CVD and cardiovascular risk factors, such as atherosclerosis, hypertension, and myocardial infarction (MI) (14-16). Patients with psychiatric disorders experience worse outcomes in response to cardiovascular disorders (e.g., higher mortality). It is suggested that appropriate monitoring for psychiatric disorders could improve outcomes in patients with ischemic heart disease $(8,14,17-21)$. Thus, research directed at minimizing the negative impact of stress is important $(19,21-25)$.

\section{Stress and Cardiovascular Disease}

Cardiovascular disease is the leading cause of mortality worldwide $(26,27)$, and stress is a well-established contributor to the development of $\operatorname{CVD}(3,8,20)$. Stress is relevant at all stages of CVD; stress can increase exposure to risk factors for CVD (e.g., smoking), the long-term development of atherosclerosis, and the triggering of cardiac events in people with CVD (28).

The most common form of CVD is ischemic heart disease (also known as coronary artery disease), which includes disease states such as angina, MI, and sudden cardiac death (SCD) $(29,30)$. MI occurs when blood flow to a region of the heart stops. The heart is an electromechanical pump; SCD most commonly occurs in response to ventricular fibrillation, a disturbance in electrical activity, as a result of acute coronary ischemia $(31,32)$. MI and SCD can lead to cardiac arrest and death. Stress may acutely trigger MI or SCD or worsen underling CVD leading to one of these events (3). Thus, stress is closely related to ischemic heart disease. Research investigating the relationship between stress and the cardiovascular system is critical to improve patient outcomes in $\operatorname{CVD}(20,25,28)$.

\section{Myocardial Ischemia-Reperfusion Injury}

Myocardial IRI refers to the damage created by the stoppage of and the subsequent restoration of blood flow to the heart. Without blood flow, an imbalance between oxygen supply and demand is created which results directly in irreversible damage to cardiac tissue, eventually resulting in apoptosis or necrosis; this oxygen imbalance is referred to as ischemia. The duration of ischemia and amount of tissue exposed to ischemia are well established as the primary determinants of infarct size (IS), or the amount of non-viable tissue following ischemia. The mechanisms by which damage and protection occur in response to myocardial IRI has been described in detail previously (33-39). Thus, myocardial IRI is the primary mechanism by which cardiac tissue is damaged in MI, SCD, cardiac bypass surgery, and organ transplantation (40). Acute and chronic stress has an impact on myocardial IRI $(3,41,42)$. Because myocardial IRI plays a major role in the morbidity and mortality associated with ischemic heart disease and MI, direct study of this pathology is desirable $(35,43-46)$. To better elucidate the mechanisms underlying CVD and ischemic injury, researchers have utilized animal models.

\section{The Utility of Animal Models in Stress Biology and Cardiovascular Disease}

Animal models are used extensively to study the relationship between stress and CVD. Animal models are especially important in studying stress biology, as they allow researchers to standardize the conditions of stress. Furthermore, a high level of experimental control and the potential to study causal neurobiological and behavioral mechanisms (with easier access to tissue samples and physiological manipulation) makes animal models advantageous for studying cardiovascular function and stress $(22,47,48)$. By using validated methodology with translational relevance to human patients, researchers can use animal models effectively to examine underlying mechanisms and potential treatment options in CVD and stress $(22,49)$.

\section{The Langendorff Isolated Heart - An Experimental Model of Ischemic Injury}

Animal models have been developed to experimentally induce and study acute ischemia both in vivo $(50,51)$ and ex vivo $(44,52,53)$. The Langendorff isolated heart preparation is one of the most extensively used animal models for the study of heart physiology and ischemia (53). In this model, crystalloid perfusates (or blood) is delivered through a cannula inserted in the ascending aorta. Retrograde flow closes the leaflets in the aortic valve, leading to perfusion of the coronary vasculature $(52,53)$. This model is commonly used to study myocardial IRI. This is accomplished by occlusion of a coronary artery (typically the left anterior descending artery), leading to regional ischemia, or by turning off flow, leading to global ischemia. This model allows the generation of data including IS, the recovery of contractile function, and electrical activity in response to induced ischemia. In regional ischemia, researchers use the IS relative to the area at risk (AAR), or the area normally perfused by the clamped artery, whereas global ischemia allows measurement of the total amount of non-viable tissue [for a complete methodological review of the Langendorff isolated heart, see Ref. (52)].

Notably, the Langendorff isolated heart system studies ischemic injury in the absence of normal humoral or neuronal stimulation, potentially limiting the translation of experimental findings to the clinical setting $(52,53)$. Furthermore, this model has additional disadvantages, including a high coronary flow rate, limited supply of high-energy phosphate, a reduced oxygen requirement, and a degree of technical skill required to perform successfully (53-55). These disadvantages have led to the development of alternative methods to study cardiovascular injury; other potentially more clinically relevant methods include altering the Langendorff 
procedure (54) or using in vivo models of cardiovascular injury (56). Despite its disadvantages, the Langendorff isolated heart system has proven invaluable to the study of myocardial IRI $(52,53)$. This model has been used effectively to identify potential strategies and pharmacological agents to decrease the amount of damage caused to the heart following MI $(43,53)$.

\section{The Langendorff Isolated Heart Preparation in Rats}

The Langendorff heart preparation is appropriate in mammalian species. Although this preparation has been used rarely in large animals or man (57-61), the most frequently used isolated heart model is that of the rat. The rat model allows for relatively low costs, easy handling, and uncomplicated equipment (53). Furthermore, the consistency of limited collateral circulation allows the study of regional ischemia in the rat. This provides an advantage over models with significant collateralization such as dog (62), guinea-pig $(62,63)$, and hamster models (63). Furthermore, the rat's consistent coronary structure makes it a better model than, for example, rabbits, whose coronary structure varies significantly between animals (64). However, it is important to recognize that the rat suffers distinct disadvantages in cardiovascular study because of its short action potential duration, which lacks a plateau phase. This makes this animal a poor choice for study of arrhythmogenesis and antiarrhythmic drugs (60, 65-68). Similarly, dogs have been shown to have elevated levels of troponin and creatine kinase, markers of cardiac damage, in response to cardiac injury (69). However, rats have only shown elevations in troponin, making them relatively poor candidates to study drug-induced injury using these markers $(69,70)$. Thus, one must remain mindful of the potential clinical relevance of studies in the context of the species being utilized (52).

Both myocardial ischemic injury and cardiovascular responses to stress have been described in detail in both human patients and animal models; however, only several recent studies have focused directly on the sensitivity to myocardial ischemic injury in response following acute or chronic psychological stress exposure.

\section{ACUTE STRESS AND CARDIOVASCULAR DISEASE}

The association between acute stress and cardiac rhythm, acute MI, SCD, and stress cardiomyopathy has been supported by epidemiological studies (71-75). Cardiac rhythm changes in response to acute stress has been evidenced by a marked increase in tachyarrhythmia among patients with implanted cardioverter defibrillators in the New York area of the USA during the attacks on the World Trade Center on September 11, 2001 (71). An association between intense emotional stress or anger and the triggering of acute cardiac events, such as acute MI or SCD, has been demonstrated by multiple studies demonstrating a significant number of patients experiencing an emotional episode roughly $2 \mathrm{~h}$ before cardiac arrest (72-75). This increased incidence of MI has been evidenced in individual patients following a significant acute stressor, such as the loss of a loved one. Moreover, acute cardiac event incidence is increased in geographical areas where a major trauma, such as an earthquake, serves as an acute stressor $(8,20,76)$. SCD and MIs are rare in patients with no underlying coronary heart disease, whereas stress cardiomyopathy can occur with no underlying disorder (77-79).

\section{Acute Stress and Myocardial Ischemic Injury}

The association between intense emotional stress and ischemic heart disease, specifically the incidence of SCD, has been researched for over 50 years $(80,81)$. Acute psychological stress in human patients leads to ischemia, stress cardiomyopathy, MI, and SCD (8). Stress cardiomyopathy is induced by intense stress that results in heart weakness without underlying pathology. Thus, stress cardiomyopathy is a recently identified disease state mirroring MI with symptoms, such as chest pain and ECG abnormalities, but without concomitant coronary spasm or ischemiainduced enzymatic release $(82,83)$. Mental stress elicits regional ischemic damage due to epicardial or microvascular constriction, as evidenced by changes in regional perfusion. Interestingly, this ischemia is not associated with the angina and ECG changes that are associated with exercise-induced stress (84-89). This transient myocardial ischemia and coronary artery constriction have been shown to occur in patients with advanced coronary artery disease in response to mental stress (89-91). Furthermore, mental stress has been shown to lead to ECG alternans, a predictor of ventricular arrhythmias and SCD (92-94).

Acute mental stress has been shown to alter the action potential duration of cardiac tissue in humans. Adrenergic stimulation with isoprenaline and adrenaline increases the steepness of the slope of action potential duration restitution; this suggests that adrenergic stimulation can lead to electrical instability, which could lead to ventricular fibrillation or arrhythmias (95). In an elegant study, Child et al. showed that a mental challenge was able to elicit this effect on action potential duration independent of the respiration or heart rate changes that occur in response to mental stress (96). Ventricular fibrillation has been shown to occur in response to both regional myocardial ischemia and electrical instability. Ventricular fibrillation leads to global cardiac ischemia, which can lead to cardiac death $(97,98)$. The ability of mental stress to cause cardiac ischemia and electrical instability in the heart is supported by epidemiological studies. The underlying risk factors inherent in clinical study complicate cardiovascular research. As previously discussed, the standardization of stress conditions makes animal models advantageous for investigating the underlying pathology of disease, including CVD.

\section{Experimental Acute Stress and Cardiovascular Disease}

Experimental work using animal models supports the effects of acute psychological stress on the cardiovascular system seen in human patients. Psychological stress has been shown to reduce the ventricular fibrillation threshold in $\operatorname{dog}(42,99-103)$ and porcine models (104). Verrier and colleagues have demonstrated the ability of acute stress to precipitate ventricular arrhythmias in dogs exposed to anger and fear in both healthy hearts and hearts exposed to coronary artery occlusion (99-103, 105-108). Acute 
stress was able to precipitate ventricular fibrillation and cardiac arrest; albeit, these studies did not utilize dogs exposed to a single acute stressor but rather an acute stress session following aversive conditioning $(99-101,103)$. These researchers found that behaviorally induced changes in vulnerability to fibrillation are mediated by the direct effects of catecholamines on beta receptors $(109,110)$. Further supporting the centrally mediated nature of cardiac arrhythmias generated by acute stress, Skinner and Reed were able to prevent an increase in ventricular fibrillation by cryogenic blockage of the forebrain, posterior hypothalamus, or fields of Forel (104). Thus, acute psychological stress has the ability to generate and exacerbate ischemia and ventricular arrhythmia.

Stress-limiting endogenous systems have been identified with the ability to abolish or reduce cardiac arrhythmias in response to sympathetic stimulation, acute stress, or ischemic injury $(4,7)$. The endogenous hormones utilized by these systems with protective effects on the cardiovascular system include GABA $(111,112)$, opioids (113), or vagal stimulation with cholinergic agonists $(114,115)$. Furthermore, it has been suggested that electrical instability does not necessarily disturb cardiac contractility $(4,116)$. Supporting the role of stress-limiting systems in cardiovascular injury, recent work in rodents demonstrates that acute stress may decrease damage in response to induced regional ischemia, possibly as a compensatory mechanism.

\section{Experimental Acute Stress and Myocardial Ischemic Injury}

Recent rodent studies looking at the effect of acute psychological stress on the impact of myocardial ischemicinjury have found acute stress to be cardioprotective and reduce IS [see Table $1(45,117)$ ]. The identified relevant studies utilized cold-restraint stress (117) and forced swim stress (45) before using the Langendorff method to induce regional ischemia. Acute swim stress and acute restraint stress are validated psychological stressors that have been used in combination with other stressors to model PTSD and depression (118-121). These stressors, individually or in combination, have resulted in anxiety-like and fear-related behavior in rodents as assessed by tests such as the elevated plus maze (EPM) and contextual fear conditioning (CF) $(119,122,123)$. The decreased sensitivity to myocardial IRI provided by acute psychological stress is supported by similar findings in studies utilizing acute physiologic stressors, such as exercise or hyperthermia (124-128). The existence of endogenous signaling pathways that protect the heart from ischemic injury is well evidenced $(46,129-131)$.

Research has previously shown that short-term stress is accompanied by enhanced contractile function and resistance to hypoxia in hearts isolated from stressed animals, while long-term stress resulted in the opposite effect $(4,7)$. Additionally, acute stressors seem to result in the redistribution of the immune system to the site of inflammation, which could provide an adaptive response to stress (137-139). Interestingly, opioid antagonists were able to eliminate the cardioprotection afforded by cold-restraint stress, supporting this stress-limiting system's role in decreased sensitivity to ischemic damage $(113,117,140)$.

Though acute psychological stress decreases the sensitivity of ischemic damage in response to myocardial IRI, the work does not necessarily contradict the previously discussed, well-established effects of acute stress in both animal models and clinical research, including triggering MI or independently leading to ischemic damage (72-75, 100-103). While electrical instability of the heart occurs in response to acute stress, it is possible that protective pathways exist to reduce the sensitivity to ischemic damage $(4,7,116,140)$. Additionally, it is important to recognize that while removing the additional stressors and underlying pathology found in humans adds experimental control, it does diminish the clinical translatability of this work $(33,52,53)$. Furthermore, while investigators look at the myocardial ischemic injury of all rodents exposed to acute psychological stress, MI data in humans in response to acute stressors typically only represent patients who experienced an MI or symptoms of an MI (72-75). As a final potential limitation, rodent models look at the same ischemic injury in all subjects, whereas human patients can present with very different ischemic damage due to underlying disease and the possible collateralization of vessels over many years (135).

Contrasting the protective effects of acute stress, chronic stress in rodent models has impacted sensitivity to myocardial ischemic injury in rodent models by decreasing recovery of cardiac contractility and increasing ischemic injury $(10,132,133,134)$. The effect of chronic psychological stress is especially relevant because of the numerous stressors facing human patients, which have effects on cardiovascular outcomes $(8,14,17-22,141,142)$. Thus, diminishing the negative effects of chronic stress on the heart has the ability to reduce cardiovascular morbidity and mortality. Therefore, the effect of chronic stress on the cardiovascular system has been an emerging area of research with several recent studies looking directly at myocardial ischemic injury.

\section{CHRONIC STRESS AND CARDIOVASCULAR DISEASE}

Chronic stress has been implicated to cause or worsen CVD in human patients $(20,141-145)$. Chronic stress has been linked to increased risk of ischemic heart disease $(20,28)$. The INTERHEART case-control study showed that significant longterm stress over the course of 12 months more than doubled the risk of acute MI, even after adjusting for conventional risk factors such as diabetes mellitus, hypertension, and smoking (146). Prospective cohort studies have supported the effect of long-term stress on risk of coronary heart disease. Studies have linked coronary heart disease risk with work-related stressors, specifically when an imbalance between effort and reward is experienced (147-151). Furthermore, the effects of long-term stress may persist long after the cessation of the chronic stressors. Survivors of the siege of Leningrad were found to have increased blood pressure and increased mortality from CVD, relative to Russians who were not in the besieged city, over 50 years after the event (152).

\section{Chronic Stress and Cardiovascular Disease}

Psychological conditions related to chronic stress and CVD include depression, anxiety, and PTSD (3). As previously discussed, psychiatric disorders can worsen outcomes in CVD. 


\begin{tabular}{|c|c|c|c|c|}
\hline Subjects & Stress protocol & Reperfusion injury (RI) protocol & Primary finding & Reference \\
\hline \multicolumn{5}{|l|}{ Acute psychological stress } \\
\hline Adult male Wistar rats & $\begin{array}{l}\text { Forced swim for } 10 \text { min } \\
\text { Rl } 10 \text { min after }\end{array}$ & $\begin{array}{l}30 \text { min ischemia } \\
60 \text { min reperfusion }\end{array}$ & $\begin{array}{l}\text { Decreased infarct size } \\
\text { (IS)/area at risk (AAR)\% }\end{array}$ & $\begin{array}{l}\text { Moghimian } \\
\text { et al. (45) }\end{array}$ \\
\hline $\begin{array}{l}\text { Adult male Sprague-Dawley } \\
\text { rats }\end{array}$ & $\begin{array}{l}\text { Individual immobilization, placed in a cold room for } 3 \mathrm{~h} \text { at } 4 \pm 0.3^{\circ} \mathrm{C} \\
\mathrm{Rl} \text { immediately after }\end{array}$ & $\begin{array}{l}30 \mathrm{~min} \text { ischemia } \\
120 \mathrm{~min} \text { reperfusion }\end{array}$ & Decreased IS/AAR\% & Wu et al. (117) \\
\hline \multicolumn{5}{|c|}{ Chronic psychological stress } \\
\hline $\begin{array}{l}\text { Adult male Sprague-Dawley } \\
\text { rats }\end{array}$ & $\begin{array}{l}1-1.5 \text { h daily restraint stress for } 8-14 \text { days } \\
\text { RI } 24 \text { h later }\end{array}$ & $\begin{array}{l}30 \text { min ischemia } \\
180 \text { min reperfusion }\end{array}$ & $\begin{array}{l}\text { Increased IS/AAR\% } \\
\text { Increased \# of fatal } \\
\text { arrhythmias }\end{array}$ & $\begin{array}{l}\text { Scheuer and } \\
\text { Mifflin (132) }\end{array}$ \\
\hline $\begin{array}{l}\text { Adult male Sprague-Dawley } \\
\text { rats }\end{array}$ & $\begin{array}{l}2 \mathrm{~h} \text { daily restraint stress for } 11-12 \text { days } \\
\text { RI } 24 \text { h later }\end{array}$ & $\begin{array}{l}30 \text { min ischemia } \\
180 \text { min reperfusion }\end{array}$ & $\begin{array}{l}\text { Increased IS/AAR\% } \\
\text { Increased \# of fatal } \\
\text { arrhythmias }\end{array}$ & $\begin{array}{l}\text { Scheuer and } \\
\text { Mifflin (132) }\end{array}$ \\
\hline $\begin{array}{l}\text { Adult male Wistar-Kyoto } \\
\text { (WKY) rats }\end{array}$ & $\begin{array}{l}\text { Crowding stress (living space } 200 \mathrm{~cm}^{2} / \text { rat) for } 8 \text { weeks } \\
\text { RI unspecified }\end{array}$ & $\begin{array}{l}30 \text { min ischemia } \\
120 \text { min reperfusion (reperfusion-induced tachyarrhythmias and } \\
\text { contractile function measured } 40 \text { min after reperfusion initiation) }\end{array}$ & $\begin{array}{l}\text { Decreased LVDP recovery } \\
\text { Increased duration of } \\
\text { ventricular tachycardia (VT) }\end{array}$ & $\begin{array}{l}\text { Ravingerova } \\
\text { et al. (133) }\end{array}$ \\
\hline $\begin{array}{l}\text { Adult male spontaneously } \\
\text { hypertensive (SHR) rats }\end{array}$ & $\begin{array}{l}\text { Crowding stress (living space } 200 \mathrm{~cm}^{2} / \text { rat) for } 8 \text { weeks } \\
\text { Rl unspecified }\end{array}$ & $\begin{array}{l}30 \mathrm{~min} \text { ischemia } \\
120 \text { min reperfusion (reperfusion-induced tachyarrhythmias and } \\
\text { contractile function measured } 40 \text { min after reperfusion initiation) }\end{array}$ & $\begin{array}{l}\text { Increased LVDP recovery } \\
\text { Decreased duration of VT }\end{array}$ & $\begin{array}{l}\text { Ravingerova } \\
\text { et al. (133) }\end{array}$ \\
\hline Adult male Wistar rats & $\begin{array}{l}10 \text { s electrical shock, } 50 \text { s rest for } 1 \mathrm{~h} \text { daily for } 7 \text { days } \\
\text { RI } 24 \mathrm{~h} \text { later }\end{array}$ & $\begin{array}{l}30 \text { min ischemia } \\
120 \text { min reperfusion }\end{array}$ & Increased IS/AAR\% & $\begin{array}{l}\text { Rakhshan } \\
\text { et al. (10) }\end{array}$ \\
\hline Adult male Wistar rats & $\begin{array}{l}\text { Witnessed rats receive but did not receive } 10 \text { s electrical shock, } 50 \text { s rest } \\
\text { for } 1 \mathrm{~h} \text { daily for } 7 \text { days (psychological shock) } \\
\text { RI } 24 \text { h later }\end{array}$ & $\begin{array}{l}30 \text { min ischemia } \\
120 \text { min reperfusion }\end{array}$ & Increased IS/AAR\% & $\begin{array}{l}\text { Rakhshan } \\
\text { et al. (10) }\end{array}$ \\
\hline $\begin{array}{l}\text { 5-week-old male } \\
\text { Wistar-Kyoto (WKY) rats }\end{array}$ & $\begin{array}{l}\text { Crowding stress ( } 70 \mathrm{~cm}^{2} \text { living space per } 100 \mathrm{~g} \text { body mass) for } 14 \text { days } \\
\text { Rl unspecified }\end{array}$ & $\begin{array}{l}30 \text { min ischemia } \\
120 \text { min reperfusion (reperfusion-induced tachyarrhythmias and } \\
\text { contractile function measured } 40 \text { min after reperfusion initiation) }\end{array}$ & $\begin{array}{l}\text { No significant difference } \\
\text { between stress and no } \\
\text { stress groups }\end{array}$ & $\begin{array}{l}\text { Ledvenyiova- } \\
\text { Farkasova } \\
\text { et al. (134) }\end{array}$ \\
\hline $\begin{array}{l}\text { 5-week-old female } \\
\text { Wistar-Kyoto (WKY) rats }\end{array}$ & $\begin{array}{l}\text { Crowding stress ( } 70 \mathrm{~cm}^{2} \text { living space per } 100 \mathrm{~g} \text { body mass) for } 14 \text { days } \\
\text { Rl unspecified }\end{array}$ & $\begin{array}{l}30 \text { min ischemia } \\
120 \text { min reperfusion (reperfusion-induced tachyarrhythmias and } \\
\text { contractile function measured } 40 \text { min after reperfusion initiation) }\end{array}$ & Decreased VT duration & $\begin{array}{l}\text { Ledvenyiova- } \\
\text { Farkasova } \\
\text { et al. (134) }\end{array}$ \\
\hline $\begin{array}{l}\text { 5-week-old female } \\
\text { spontaneously hypertensive } \\
\text { (SHR) rats }\end{array}$ & $\begin{array}{l}\text { Crowding stress ( } 70 \mathrm{~cm}^{2} \text { living space per } 100 \mathrm{~g} \text { body mass) for } 14 \text { days } \\
\text { Rl unspecified }\end{array}$ & $\begin{array}{l}30 \text { min ischemia } \\
120 \text { min reperfusion (reperfusion-induced tachyarrhythmias and } \\
\text { contractile function measured } 40 \text { min after reperfusion initiation) }\end{array}$ & Increased VT duration & $\begin{array}{l}\text { Ledvenyiova- } \\
\text { Farkasova } \\
\text { et al. (134) }\end{array}$ \\
\hline $\begin{array}{l}\text { 5-week-old male } \\
\text { spontaneously hypertensive } \\
\text { (SHR) rats }\end{array}$ & $\begin{array}{l}\text { Crowding stress ( } 70 \mathrm{~cm}^{2} \text { living space per } 100 \mathrm{~g} \text { body mass) for } 14 \text { days } \\
\text { Rl unspecified }\end{array}$ & $\begin{array}{l}30 \text { min ischemia } \\
120 \text { min reperfusion (reperfusion-induced tachyarrhythmias and } \\
\text { contractile function measured } 40 \text { min after reperfusion initiation) }\end{array}$ & Increased VT duration & $\begin{array}{l}\text { Ledvenyiova- } \\
\text { Farkasova } \\
\text { et al. (134) }\end{array}$ \\
\hline $\begin{array}{l}\text { Adult male Sprague-Dawley } \\
\text { rats }\end{array}$ & $\begin{array}{l}31 \text { days chronic social instability (randomized paired housing) } \\
1 \mathrm{~h} \text { immobilized predator exposure on days } 1 \text { and } 11 \\
\text { See Zoladz et al. (136) for complete PTSD paradigm RI } 48 \text { h later }\end{array}$ & $\begin{array}{l}20 \text { min ischemia } \\
120 \text { min reperfusion }\end{array}$ & $\begin{array}{l}\text { Increased IS/AAR\% } \\
\text { Decreased RPP } \\
\text { Decreased + dP/dT }\end{array}$ & $\begin{array}{l}\text { Rorabaugh } \\
\text { et al. (135) }\end{array}$ \\
\hline $\begin{array}{l}\text { Adult female } \\
\text { Sprague-Dawley rats }\end{array}$ & $\begin{array}{l}31 \text { days chronic social instability (randomized paired housing) } \\
1 \mathrm{~h} \text { immobilized predator exposure on days } 1 \text { and } 11 \\
\text { See Zoladz et al. (136) for complete PTSD paradigm } \\
\text { RI } 48 \mathrm{~h} \text { after }\end{array}$ & $\begin{array}{l}20 \text { min ischemia } \\
120 \text { min reperfusion }\end{array}$ & No significant effect & $\begin{array}{l}\text { Rorabaugh } \\
\text { et al. (135) }\end{array}$ \\
\hline
\end{tabular}


However, this relationship may be bidirectional. For example, it has been shown that coronary heart disease leads to a higher incidence of depression, and depression leads to worse outcomes in coronary heart disease $(14,15,17,49,153)$. Furthermore, the association between depression and coronary heart disease occurs independent of comorbid risk factors such as high cholesterol, hypertension, or obesity $(13,49,154,155)$. PTSD also increases a patient's risk for developing coronary heart disease. This association is independent of comorbid depression, genetic influences, and other confounding factors (156-158). The negative cardiovascular outcomes exhibited in both depression and PTSD have been attributed to underlying dysfunction in the autonomic nervous system and HPA axis (13, 22, 48, 49, 135). However, precisely defining the contribution of long-term stress to CVD is difficult due to potential confounding factors including the aforementioned psychological disorders (28). Thus, animal models provide an acceptable means to study chronic stress in the controlled experimental setting (22).

\section{Experimental Chronic Stress and Cardiovascular Disease}

Animal models support the negative effects of chronic stress on the cardiovascular system evidenced by epidemiological studies. Experimental studies have found exposure to chronic stress results in enhanced development of atherosclerosis and plaque destabilization $(3,159,160)$. Chronic stress has also been shown to lower the threshold for ventricular arrhythmias (103, 107-109, 161, 162). In a landmark study, Verrier and Lown conditioned dogs to associate a sling with an aversive shock for 3 days. On days 4 and 5, these researchers found that coronary occlusion in dogs re-exposed to the sling environment (in the absence of shock) led to ventricular fibrillation, whereas dogs in a non-aversive cage environment did not experience ventricular fibrillation. Research has continued to focus on this ability of chronic psychological stress to result in cardiac instability $(101,102,107)$.

Researchers have used validated models of psychological disorders to study the relationship between psychological disorders and the cardiovascular system. For example, the relationship between depression and CVD has been studied using chronic stress models [e.g., chronic mild stress (CMS) and social isolation] of depression in rodents. The CMS model of depression involves exposure to mild and unpredictable stressors, including changing cage mates, cage tilt, and periods of water or food deprivation, for a period greater than 2 weeks $(49,153,163)$. These models of depression decrease rodent intake of a sweet solution, suggestive of anhedonia. Rodents exposed to these well-established animal models display depressive-like behavior, and have a decreased threshold for arrhythmias and tissue fibrosis $(22,49,153,163-167)$. Although animal models have been used to study stress biology and cardiovascular outcomes, few studies exist using validated models of psychological disorders to study the effect of stress on sensitivity to myocardial ischemic injury.

\section{Experimental Chronic Stress and Myocardial Ischemic Injury}

In several recent rodent studies, researchers have found greater ISs, decreased cardiac output, and decreased recovery of contractile function in response to chronic psychological stress [see Table 1 (10, 132, 133, 134, 135)]. Chronic physiologic stress has previously shown mixed results; both decreased (168) and increased (169) sensitivity to myocardial ischemic injury have been reported. Evidencing only negative effects of chronic stress on myocardial ischemic injury, the impact of chronic psychological stress represents an emerging area of research to minimize the detrimental effect of chronic stress $(135,170)$. The disruptive effect of chronic psychological stress exposure on myocardial ischemic injury has been demonstrated using several different chronic stressors, including chronic restraint stress (132), daily foot shocks or witnessing rats receiving those foot shocks (10), or crowding stress $(133,134)$.

These stressors are frequently utilized in modeling psychological disorders that result from stress. Restraint stress has been used as a psychological stressor in rats and has been utilized in combination with other stressors to model PTSD and depression $(119,122,123,136)$. Inescapable footshock is used to model depressive symptoms in rodents. Rats exposed to inescapable footshock have demonstrated anxiety-like behavior on an EPM, impaired growth rates, decreased rearing in an open field, and decreased locomotion (50, 171-173). Crowding stress is a well-known and ethologically valid model of psychological stress in rats which causes social competition for resources, such as space, food, and water. Crowding stress results in behavioral and physiologic data reflecting psychological stress (174-178). These chronic psychological stressors resulted in disruption to the cardiovascular system following induced myocardial ischemic injury, either by causing increased IS and decreased contractile function recovery (10, 132) or only decreased contractile function recovery $(133,134)$. These studies suggest that chronic stress not only increases the likelihood of a MI or SCD but also exacerbates the damage in response to ischemic injury.

A potential limitation of these studies is that researchers did not take behavioral measures of stress prior to myocardial ischemic injury. Although the methods of stress used to stress these animals are validated as methods of inducing psychological stress, individual susceptibility may play a role in the response of the animal to a psychological stressor $(10,132,133,134)$. Stress exposure may affect animals differently, and thus, measurement of the stress response at the behavioral level is important. The only known published study utilizing a model of a chronic psychological disorder where animals' response to stress was validated prior to myocardial ischemic injury is utilizing a predator-based psychosocial model of PTSD (135).

\section{A Predator-Based Psychosocial Model of PTSD and Myocardial Ischemia-Reperfusion Injury}

A predator-based psychosocial model of PTSD has been utilized to study sensitivity to myocardial ischemic injury. This model involves two 1-h cat exposures, during which rats are restrained while they can see, smell, and hear a cat but cannot be physically harmed. The two exposures are separated by a period of 10 days. Starting on the day of the first cat exposure, rodents experience chronic social instability by having their housing partner changed daily for 31 days. After the 31-day paradigm, 
rats exhibit a fear memory associated with the cat exposures (evidenced by freezing in response to conditioned context and cues), heightened anxiety-like behavior on the EPM, an exaggerated startle response, and impaired memory for newly learned information. Furthermore, rats exposed to this paradigm have demonstrated physiological changes reflecting elevated SNS activity and HPA axis abnormalities, including elevated heart rate and blood pressure, decreased baseline corticosterone levels, and enhanced negative feedback of the HPA axis (135, 136, 179-181). Replicating and expanding on these results, researchers utilizing this model have shown stressed rats exhibit decreased serotonin, increased norepinephrine, and increased measures of oxidative stress and inflammation in the brain, adrenal glands, and systemic circulation $(182,183)$.

Recently, we found that, subsequent to this chronic psychological stress paradigm, male rats exposed to myocardial ischemic injury exhibited greater ISs and decreased recovery of contractile function [Figure 1 (135)]. The disruptive effect of this PTSD paradigm on the heart is further strengthened by anxiety-like behavior in rats on the EPM prior to myocardial ischemic injury. These data suggest that the psychological stress induced by the PTSD paradigm is having an effect directly on the heart, causing the heart to be more susceptible to damage following a MI (135). The ability of chronic stress to worsen the extent of ischemic injury and decrease the recovery of cardiac contractility further exacerbates the supported negative effects of stress in CVD, which make rodents exposed to chronic stress more susceptible to ventricular fibrillation and MI $(13,22,48,49,135)$.

\section{THE IMPORTANCE OF THE EFFECT OF PSYCHOLOGICAL STRESS ON MYOCARDIAL ISCHEMIA-REPERFUSION INJURY}

Shown presently, acute and chronic psychological stress affects sensitivity to myocardial ischemic injury in opposite directions; acute psychological stress decreases, whereas chronic psychological stress increases sensitivity to myocardial ischemic injury $(45,117)$. It is possible that protective mechanisms exist in response to an optimal level of acute stress, but these mechanisms are eventually overcome by more intense levels of stress (4).

Physiologically, a possible explanation for this differential effect is that acute psychological stress causes norepinephrine release and acute alpha stimulation, which results in ischemic preconditioning $(184,185)$. Chronic psychological stress may result in chronic beta stimulation, worsening the ischemic injury (186-190). The previously discussed advantages of the isolated rat heart (66), the wide variety of validated psychological stressors in rodents $(119,122,123,136,174-178)$, and the existence of rodent models of psychiatric disorders $(49,153,181)$ add weight to the presently discussed findings. However, it is important to qualify

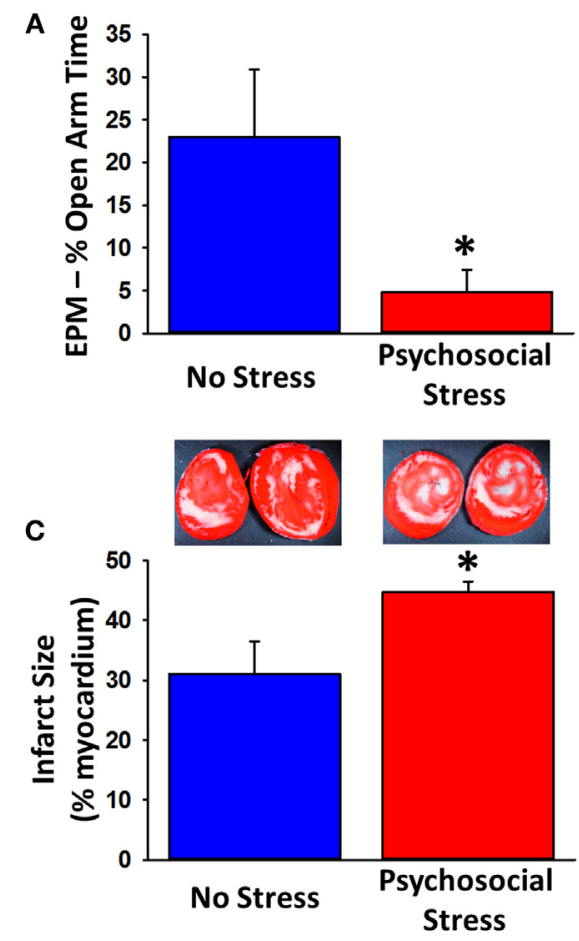

B
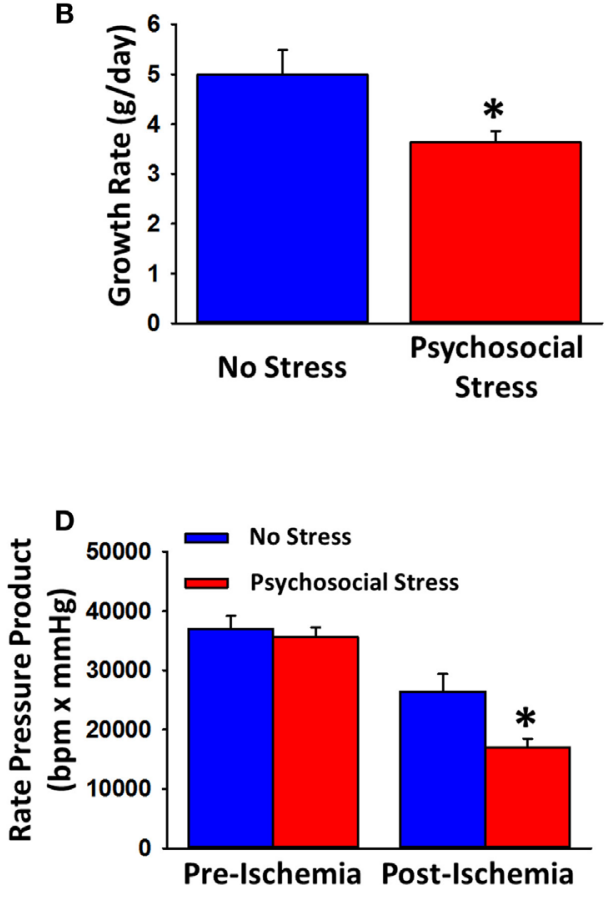

FIGURE 1 | Effects of a predator-based psychosocial model of PTSD on anxiety-like behavior, growth rate, and myocardial sensitivity to ischemic injury. Rats exposed to the 31-day psychosocial stress paradigm spend less time in the open arms on the EPM (A) and exhibit reduced growth rats (B). Following 20-min ischemia, hearts from psychosocially stressed animals exhibit larger infarcts (C), white regions of representative tissue (samples in the insets) and impaired recovery of contractile function (D). Data are means \pm SEM. ${ }^{*} p<0.05$ relative to no stress. Adapted from Rorabaugh et al. (135). 
these findings by recognizing the methodological differences in a limited amount of studies and the previously discussed weaknesses of translating the isolated rodent heart to humans.

Utilizing ethologically valid models of stress to further study the effect of psychological stress on myocardial ischemic injury will best translate to improving patient outcomes in the clinical setting $(22,49)$. Additionally, further research investigating the effects of stress on the cardiovascular system in females will be important in translating findings to the clinical setting, as the current literature is currently dominated by studies in male subjects (135).

\section{CONCLUSION}

The relationship between stress and CVD continues to receive a substantial amount of attention. Here, we reviewed research

\section{REFERENCES}

1. Cannon WB. Stresses and strains of homeostasis. Am J Med Sci (1935) 189(1):13-4. doi:10.1097/00000441-193501000-00001

2. Selye H. The story of the adaptation syndrome. Am JMed Sci (1952) 224(6):711. doi:10.1097/00000441-195212000-00039

3. Lagraauw HM, Kuiper J, Bot I. Acute and chronic psychological stress as risk factors for cardiovascular disease: insights gained from epidemiological, clinical and experimental studies. Brain Behav Immun (2015) 50:18-30. doi:10.1016/j.bbi.2015.08.007

4. Meerson FZ. Stress-induced arrhythmic disease of the heart - part I. Clin Cardiol (1994) 17(7):362-71. doi:10.1002/clc.4960170705

5. McEwen BS. Protective and damaging effects of stress mediators. N Engl J Med (1998) 338(3):171-9. doi:10.1056/NEJM199801153380307

6. Meijer OC. Understanding stress through the genome. Stress (2006) 9(2):61-7. doi:10.1080/10253890600799669

7. Meerson FZ. Adaptive Protection of the Heart. Boca Raton, FL: CRC Press (1990).

8. Dimsdale JE. Psychological stress and cardiovascular disease. J Am Coll Cardiol (2008) 51(13):1237-46. doi:10.1016/j.jacc.2007.12.024

9. Johnson EO, Kamilaris TC, Chrousos GP, Gold PW. Mechanisms of stress: a dynamic overview of hormonal and behavioral homeostasis. Neurosci Biobehav Rev (1992) 16(2):115-30. doi:10.1016/S0149-7634(05)80175-7

10. Rakhshan K, Imani A, Faghihi M, Nabavizadeh F, Golnazari M, Karimian S. Evaluation of chronic physical and psychological stress induction on cardiac ischemia/reperfusion injuries in isolated male rat heart: the role of sympathetic nervous system. Acta Med Iran (2015) 53(8):482-90.

11. Tennant C, Langeluddecke P, Byrne D. The concept of stress. Aust N Z J Psychiatry (1985) 19(2):113-8. doi:10.3109/00048678509161308

12. Parker GB, Owen CA, Brotchie HL, Hyett MP. The impact of differing anxiety disorders on outcome following an acute coronary syndrome: time to start worrying? Depress Anxiety (2010) 27(3):302-9. doi:10.1002/da.20602

13. Penninx BW, Beekman AT, Honig A, Deeg DJ, Schoevers RA, van Eijk JT, et al. Depression and cardiac mortality: results from a community-based longitudinal study. Arch Gen Psychiatry (2001) 58(3):221-7. doi:10.1001/ archpsyc.58.3.221

14. Anda R, Williamson D, Jones D, Macera C, Eaker E, Glassman A, et al. Depressed affect, hopelessness, and the risk of ischemic heart disease in a cohort of U.S. adults. Epidemiology (1993) 4(4):285-94. doi:10.1097/00001648-199307000-00003

15. Mavrides N, Nemeroff C. Treatment of depression in cardiovascular disease. Depress Anxiety (2013) 30(4):328-41. doi:10.1002/da.22051

16. Mavrides N, Nemeroff CB. Treatment of affective disorders in cardiac disease. Dialogues Clin Neurosci (2015) 17(2):127-40.

17. Barefoot JC, Helms MJ, Mark DB, Blumenthal JA, Califf RM, Haney TL, et al. Depression and long-term mortality risk in patients with coronary artery disease. Am J Cardiol (1996) 78(6):613-7. doi:10.1016/S0002-9149(96) 00380-3 studying the sensitivity of the rodent heart to ischemic injury in response acute and chronic psychological stress in the context of clinical and experimental studies on the effects of stress on the cardiovascular system. Elucidation of stress-limiting systems will help identify novel therapeutic options to decrease cardiovascular mortality. Further research investigating the relationship between acute and chronic stress and ischemic injury will improve patient care with implications that extend beyond cardiovascular disease.

\section{AUTHOR CONTRIBUTIONS}

EE wrote the first draft of the manuscript and revised it following peer review. BR provided comments on each draft. PZ helped EE prepare the manuscript, provided comments on each draft, and prepared the figures.

18. Ketterer MW. Secondary prevention of ischemic heart disease. The case for aggressive behavioral monitoring and intervention. Psychosomatics (1993) 34(6):478-84. doi:10.1016/S0033-3182(93)71821-6

19. Monroe SM, Harkness KL. Life stress, the "kindling" hypothesis, and the recurrence of depression: considerations from a life stress perspective. Psychol Rev (2005) 112(2):417-45. doi:10.1037/0033-295X.112.2.417

20. Steptoe A, Kivimaki M. Stress and cardiovascular disease: an update on current knowledge. Annu Rev Public Health (2013) 34:337-54. doi:10.1146/ annurev-publhealth-031912-114452

21. Swaab DF, Bao AM, Lucassen PJ. The stress system in the human brain in depression and neurodegeneration. Ageing Res Rev (2005) 4(2):141-94. doi:10.1016/j.arr.2005.03.003

22. Grippo AJ. The utility of animal models in understanding links between psychosocial processes and cardiovascular health. Soc Personal Psychol Compass (2011) 5(4):164-79. doi:10.1111/j.1751-9004.2011.00342.x

23. Gianaros PJ, Wager TD. Brain-body pathways linking psychological stress and physical health. Curr Dir Psychol Sci (2015) 24(4):313-21. doi:10.1177/0963721415581476

24. Richtig E, Trapp EM, Avian A, Brezinsek HP, Trapp M, Egger JW, et al. Psychological stress and immunological modulations in early-stage melanoma patients. Acta Derm Venereol (2015) 95(6):691-5. doi:10.2340/00015555-2045

25. Davey A, Shukla A, Sharma P, Srivastava K, Davey S, Vyas S. Are the adverse psychiatric outcomes reflection of occupational stress among nurses: an exploratory study. Asian J Med Sci (2016) 7(1):96-100. doi:10.3126/ajms. v7i1.12869

26. Mathers CD, Loncar D. Projections of global mortality and burden of disease from 2002 to 2030. PLoS Med (2006) 3(11):e442. doi:10.1371/journal. pmed.0030442

27. Quam L, Smith R, Yach D. Rising to the global challenge of the chronic disease epidemic. Lancet (2006) 368(9543):1221-3. doi:10.1016/ S0140-6736(06)69422-1

28. Steptoe A, Kivimaki M. Stress and cardiovascular disease. Nat Rev Cardiol (2012) 9(6):360-70. doi:10.1038/nrcardio.2012.45

29. GBD 2013 Mortality and Causes of Death Collaborators. Global, regional, and national age-sex specific all-cause and cause-specific mortality for 240 causes of death, 1990-2013: a systematic analysis for the Global Burden of Disease Study 2013. Lancet (2015) 385(9963):117-71. doi:10.1016/S0140-6736(14) 61682-2

30. Mendis S, Puska P, Norrving B. Global Atlas on Cardiovascular Disease Prevention and Control. Geneva: World Health Organization (2011).

31. Janse MJ. Electrophysiological changes in heart failure and their relationship to arrhythmogenesis. Cardiovasc Res (2004) 61(2):208-17. doi:10.1016/j. cardiores.2003.11.018

32. Janse MJ, Wit AL. Electrophysiological mechanisms of ventricular arrhythmias resulting from myocardial ischemia and infarction. Physiol Rev (1989) 69(4):1049-169.

33. Braunwald E, Kloner RA. Myocardial reperfusion: a double-edged sword? J Clin Invest (1985) 76(5):1713-9. doi:10.1172/JCI112160 
34. Eefting F, Rensing B, Wigman J, Pannekoek WJ, Liu WM, Cramer MJ, et al. Role of apoptosis in reperfusion injury. Cardiovasc Res (2004) 61(3):414-26. doi:10.1016/j.cardiores.2003.12.023

35. Frank A, Bonney M, Bonney S, Weitzel L, Koeppen M, Eckle T. Myocardial ischemia reperfusion injury: from basic science to clinical bedside. Semin Cardiothorac Vasc Anesth (2012) 16(3):123-32. doi:10.1177/1089253211436350

36. Gottlieb RA, Burleson KO, Kloner RA, Babior BM, Engler RL. Reperfusion injury induces apoptosis in rabbit cardiomyocytes. J Clin Invest (1994) 94(4):1621-8. doi:10.1172/JCI117504

37. Rao PR, Kumar VK, Viswanath RK, Subbaraju GV. Cardioprotective activity of alcoholic extract of Tinospora cordifolia in ischemia-reperfusion induced myocardial infarction in rats. Biol Pharm Bull (2005) 28(12):2319-22. doi:10.1248/bpb.28.2319

38. Wang QD, Swardh A, Sjoquist PO. Relationship between ischaemic time and ischaemia/reperfusion injury in isolated Langendorffperfused mouse hearts. Acta Physiol Scand (2001) 171(2):123-8. doi:10.1046/j.1365-201x.2001.00788.x

39. Jennings RB, Sommers HM, Smyth GA, Flack HA, Linn H. Myocardial necrosis induced by temporary occlusion of a coronary artery in the dog. Arch Pathol (1960) 70:68-78.

40. McMichael M, Moore RM. Ischemia-reperfusion injury pathophysiology, part I. J Vet Emerg Crit Care (2004) 14(4):231-41. doi:10.1111/j.1476-4431.2004. 04004.x

41. Taggart P, Critchley H, Lambiase PD. Heart-brain interactions in cardiac arrhythmia. Heart (2011) 97(9):698-708. doi:10.1136/hrt.2010.209304

42. Verrier RL. Behavioral stress, myocardial ischemia, and arrhythmias. In: Zipes DP, Jalife J, editors. Cardiac Electrophysiology: From Cell to Bedside. Toronto: WB Saunders (1990). p. 343-52.

43. Kocoglu H, Karaaslan K, Gonca E, Bozdogan O, Gulcu N. Preconditioning effects of dexmedetomidine on myocardial ischemia/reperfusion injury in rats. Curr Ther Res Clin Exp (2008) 69(2):150-8. doi:10.1016/j.curtheres.2008. 04.003

44. Mirica SN, Ordodi V, Apostol A, Ana D, Răducan A, Duicu O, et al. Langendorff perfused heart - the 110 years old experimental model that gets better with age. Studia Univ Vasile Goldis Seria Stiintele Vietii (2009) 19(1):81-6.

45. Moghimian M, Faghihi M, Karimian SM, Imani A. The effect of acute stress exposure on ischemia and reperfusion injury in rat heart: role of oxytocin. Stress (2012) 15(4):385-92. doi:10.3109/10253890.2011.630436

46. Murphy E, Steenbergen C. Mechanisms underlying acute protection from cardiac ischemia-reperfusion injury. Physiol Rev (2008) 88(2):581-609. doi:10.1152/physrev.00024.2007

47. Neumann ID, Wegener G, Homberg JR, Cohen H, Slattery DA, Zohar J, et al. Animal models of depression and anxiety: what do they tell us about human condition? Prog Neuropsychopharmacol Biol Psychiatry (2011) 35(6):1357-75. doi:10.1016/j.pnpbp.2010.11.028

48. Zoladz PR, Diamond DM. Current status on behavioral and biological markers of PTSD: a search for clarity in a conflicting literature. Neurosci Biobehav $\operatorname{Rev}(2013)$ 37(5):860-95. doi:10.1016/j.neubiorev.2013.03.024

49. Grippo AJ. Mechanisms underlying altered mood and cardiovascular dysfunction: the value of neurobiological and behavioral research with animal models. Neurosci Biobehav Rev (2009) 33(2):171-80. doi:10.1016/j. neubiorev.2008.07.004

50. Li H, Zhou C, Chen D, Fang N, Yao Y, Li L. Failure to protect against myocardial ischemia-reperfusion injury with sevoflurane postconditioning in old rats in vivo. Acta Anaesthesiol Scand (2013) 57(8):1024-31. doi:10.1111/ aas. 12156

51. Nagata T, Yasukawa H, Kyogoku S, Oba T, Takahashi J, Nohara S, et al. Cardiac-specific SOCS3 deletion prevents in vivo myocardial ischemia reperfusion injury through sustained activation of cardioprotective signaling molecules. PLoS One (2015) 10(5):e0127942. doi:10.1371/journal. pone. 0127942

52. Bell RM, Mocanu MM, Yellon DM. Retrograde heart perfusion: the Langendorff technique of isolated heart perfusion. J Mol Cell Cardiol (2011) 50(6):940-50. doi:10.1016/j.yjmcc.2011.02.018

53. Skrzypiec-Spring M, Grotthus B, Szelag A, Schulz R. Isolated heart perfusion according to Langendorff - still viable in the new millennium. J Pharmacol Toxicol Methods (2007) 55(2):113-26. doi:10.1016/j.vascn.2006.05.006
54. Ye JX, Chen DZ. Novel cardioprotective strategy combining three different preconditioning methods to prevent ischemia/reperfusion injury in aged hearts in an improved rabbit model. Exp Ther Med (2015) 10(4):1339-47. doi:10.3892/etm.2015.2680

55. Suzuki Y, Yeung AC, Ikeno F. The pre-clinical animal model in the translational research of interventional cardiology. JACC Cardiovasc Interv (2009) 2(5):373-83. doi:10.1016/j.jcin.2009.03.004

56. Vidavalur R, Swarnakar S, Thirunavukkarasu M, Samuel SM, Maulik N. Ex vivo and in vivo approaches to study mechanisms of cardioprotection targeting ischemia/reperfusion (i/r) injury: useful techniques for cardiovascular drug discovery. Curr Drug Discov Technol (2008) 5(4):269-78. doi:10.2174/157016308786733555

57. Ytrehus K. The ischemic heart - experimental models. Pharmacol Res (2000) 42(3):193-203. doi:10.1006/phrs.2000.0669

58. Hill AJ, Laske TG, Coles JA Jr, Sigg DC, Skadsberg ND, Vincent SA, et al. In vitro studies of human hearts. Ann Thorac Surg (2005) 79(1):168-77. doi:10.1016/j.athoracsur.2004.06.080

59. Sutherland FJ, Hearse DJ. The isolated blood and perfusion fluid perfused heart. Pharmacol Res (2000) 41(6):613-27. doi:10.1006/phrs.1999.0653

60. Hearse DJ, Sutherland FJ. Experimental models for the study of cardiovascular function and disease. Pharmacol Res (2000) 41(6):597-603. doi:10.1006/ phrs. 1999.0651

61. Verdouw PD, van den Doel MA, de Zeeuw S, Duncker DJ. Animal models in the study of myocardial ischaemia and ischaemic syndromes. Cardiovasc Res (1998) 39(1):121-35. doi:10.1016/S0008-6363(98)00069-8

62. Maxwell MP, Hearse DJ, Yellon DM. Species variation in the coronary collateral circulation during regional myocardial ischaemia: a critical determinant of the rate of evolution and extent of myocardial infarction. Cardiovasc Res (1987) 21(10):737-46. doi:10.1093/cvr/21.10.737

63. Johns TN, Olson BJ. Experimental myocardial infarction. I. A method of coronary occlusion in small animals. Ann Surg (1954) 140(5):675-82. doi:10.1097/00000658-195411000-00006

64. Day SB, Johnson JA. The distribution of the coronary arteries of the rabbit. Anat Rec (1958) 132(4):633-43. doi:10.1002/ar.1091320411

65. Rees SA, Curtis MJ. Selective IK blockade as an antiarrhythmic mechanism: effects of UK66, 914 on ischaemia and reperfusion arrhythmias in rat and rabbit hearts. Br J Pharmacol (1993) 108(1):139-45. doi:10.111 1/j.1476-5381.1993.tb13453.x

66. Curtis MJ. Characterisation, utilisation and clinical relevance of isolated perfused heart models of ischaemia-induced ventricular fibrillation. Cardiovasc Res (1998) 39(1):194-215. doi:10.1016/S0008-6363(98)00083-2

67. Rees SA, Curtis MJ. Specific IK1 blockade: a new antiarrhythmic mechanism? Effect of RP58866 on ventricular arrhythmias in rat, rabbit, and primate. Circulation (1993) 87(6):1979-89. doi:10.1161/01.CIR.87.6.1979

68. Curtis MJ, Macleod BA, Walker MJ. Models for the study of arrhythmias in myocardial ischaemia and infarction: the use of the rat. J Mol Cell Cardiol (1987) 19(4):399-419. doi:10.1016/S0022-2828(87)80585-0

69. Feng X, Taggart P, Hall L, Bryant S, Sansone J, Kemmerer M, et al. Limited additional release of cardiac troponin I and $\mathrm{T}$ in isoproterenol-treated beagle dogs with cardiac injury. Clin Chem (2005) 51(7):1305-7. doi:10.1373/ clinchem.2005.049643

70. Bleuel H, Deschl U, Bertsch T, Bolz G, Rebel W. Diagnostic efficiency of troponin T measurements in rats with experimental myocardial cell damage. Exp Toxicol Pathol (1995) 47(2-3):121-7. doi:10.1016/S0940-2993(11)80297-6

71. Steinberg JS, Arshad A, Kowalski M, Kukar A, Suma V, Vloka M, et al. Increased incidence of life-threatening ventricular arrhythmias in implantable defibrillator patients after the World Trade Center attack. J Am Coll Cardiol (2004) 44(6):1261-4. doi:10.1016/j.jacc.2004.06.032

72. Steptoe A, Brydon L. Emotional triggering of cardiac events. Neurosci Biobehav Rev (2009) 33(2):63-70. doi:10.1016/j.neubiorev.2008.04.010

73. Chan C, Elliott J, Troughton R, Frampton C, Smyth D, Crozier I, et al. Acute myocardial infarction and stress cardiomyopathy following the Christchurch earthquakes. PLoS One (2013) 8(7):e68504. doi:10.1371/ journal.pone.0068504

74. Moller J, Theorell T, de Faire U, Ahlbom A, Hallqvist J. Work related stressful life events and the risk of myocardial infarction. Case-control and case-crossover analyses within the Stockholm heart epidemiology programme (SHEEP). J Epidemiol Community Health (2005) 59(1):23-30. doi:10.1136/jech.2003.019349 
75. Mittleman MA, Maclure M, Sherwood JB, Mulry RP, Tofler GH, Jacobs SC, et al. Triggering of acute myocardial infarction onset by episodes of anger. Determinants of Myocardial Infarction Onset Study Investigators. Circulation (1995) 92(7):1720-5. doi:10.1161/01.CIR.92.7.1720

76. Krantz DS, Kop WJ, Santiago HT, Gottdiener JS. Mental stress as a trigger of myocardial ischemia and infarction. Cardiol Clin (1996) 14(2):271-87. doi:10.1016/S0733-8651(05)70280-0

77. Brotman DJ, Golden SH, Wittstein IS. The cardiovascular toll of stress. Lancet (2007) 370(9592):1089-100. doi:10.1016/S0140-6736(07)61305-1

78. Wittstein IS, Thiemann DR, Lima JA, Baughman KL, Schulman SP, Gerstenblith G, et al. Neurohumoral features of myocardial stunning due to sudden emotional stress. N Engl J Med (2005) 352(6):539-48. doi:10.1056/ NEJMoa043046

79. Sharkey SW, Windenburg DC, Lesser JR, Maron MS, Hauser RG, Lesser JN, et al. Natural history and expansive clinical profile of stress (tako-tsubo) cardiomyopathy. J Am Coll Cardiol (2010) 55(4):333-41. doi:10.1016/j. jacc.2009.08.057

80. Engel GL. Sudden and rapid death during psychological stress. Folklore or folk wisdom?AnnInternMed(1971)74(5):771-82.doi:10.7326/0003-4819-74-5-771

81. Engel GL. Psychologic stress, vasodepressor (vasovagal) syncope, and sudden death. Ann Intern Med (1978) 89(3):403-12. doi:10.7326/0003-4819-89-3-403

82. Akashi YJ, Nef HM, Mollmann H, Ueyama T. Stress cardiomyopathy. Annu Rev Med (2010) 61:271-86. doi:10.1146/annurev.med.041908.191750

83. Tsuchihashi K, Ueshima K, Uchida T, Oh-mura N, Kimura K, Owa M, et al. Transient left ventricular apical ballooning without coronary artery stenosis: a novel heart syndrome mimicking acute myocardial infarction. Angina Pectoris-Myocardial Infarction Investigations in Japan. J Am Coll Cardiol (2001) 38(1):11-8. doi:10.1016/S0735-1097(01)01316-X

84. Rozanski A, Bairey CN, Krantz DS, Friedman J, Resser KJ, Morell M, et al. Mental stress and the induction of silent myocardial ischemia in patients with coronary artery disease. N Engl J Med (1988) 318(16):1005-12. doi:10.1056/ NEJM198804213181601

85. Deanfield JE, Shea M, Kensett M, Horlock P, Wilson RA, de Landsheere CM, et al. Silent myocardial ischaemia due to mental stress. Lancet (1984) 2(8410):1001-5. doi:10.1016/S0140-6736(84)91106-1

86. Pimple P, Shah A, Rooks C, Bremner JD, Nye J, Ibeanu I, et al. Association between anger and mental stress-induced myocardial ischemia. Am Heart J (2015) 169(1):115.e-21.e. doi:10.1016/j.ahj.2014.07.031

87. Burg MM, Jain D, Soufer R, Kerns RD, Zaret BL. Role of behavioral and psychological factors in mental stress-induced silent left ventricular dysfunction in coronary artery disease. J Am Coll Cardiol (1993) 22(2):440-8. doi:10.1016/0735-1097(93)90048-6

88. Gottdiener JS, Krantz DS, Howell RH, Hecht GM, Klein J, Falconer JJ, et al. Induction of silent myocardial ischemia with mental stress testing: relation to the triggers of ischemia during daily life activities and to ischemic functional severity. J Am Coll Cardiol (1994) 24(7):1645-51. doi:10.1016/0735-1097(94)90169-4

89. Becker LC, Pepine CJ, Bonsall R, Cohen JD, Goldberg AD, Coghlan C, et al. Left ventricular, peripheral vascular, and neurohumoral responses to mental stress in normal middle-aged men and women. Reference Group for the Psychophysiological Investigations of Myocardial Ischemia (PIMI) study. Circulation (1996) 94(11):2768-77. doi:10.1161/01.CIR.94.11.2768

90. Strike PC, Steptoe A. Systematic review of mental stress-induced myocardial ischaemia. Eur Heart J (2003) 24(8):690-703. doi:10.1016/ S0195-668X(02)00615-2

91. Yeung AC, Vekshtein VI, Krantz DS, Vita JA, Ryan TJ Jr, Ganz P, et al. The effect of atherosclerosis on the vasomotor response of coronary arteries to mental stress. N Engl J Med (1991) 325(22):1551-6. doi:10.1056/ NEJM199111283252205

92. Rosenbaum DS, Jackson LE, Smith JM, Garan H, Ruskin JN, Cohen RJ. Electrical alternans and vulnerability to ventricular arrhythmias. N Engl J Med (1994) 330(4):235-41. doi:10.1056/NEJM199401273300402

93. Kop WJ, Krantz DS, Nearing BD, Gottdiener JS, Quigley JF, O'Callahan M, et al. Effects of acute mental stress and exercise on T-wave alternans in patients with implantable cardioverter defibrillators and controls. Circulation (2004) 109(15):1864-9. doi:10.1161/01.CIR.0000124726.72615.60

94. Kovach JA, Nearing BD, Verrier RL. Angerlike behavioral state potentiates myocardial ischemia-induced T-wave alternans in canines. J Am Coll Cardiol (2001) 37(6):1719-25. doi:10.1016/S0735-1097(01)01196-2
95. Taggart P, Sutton P, Chalabi Z, Boyett MR, Simon R, Elliott D, et al. Effect of adrenergic stimulation on action potential duration restitution in humans. Circulation (2003) 107(2):285-9. doi:10.1161/01.CIR.0000044941.13346.74

96. Child N, Hanson B, Bishop M, Rinaldi CA, Bostock J, Western D, et al. Effect of mental challenge induced by movie clips on action potential duration in normal human subjects independent of heart rate. Circ Arrhythm Electrophysiol (2014) 7(3):518-23. doi:10.1161/CIRCEP.113.000909

97. Bradley CP, Clayton RH, Nash MP, Mourad A, Hayward M, Paterson DJ, et al. Human ventricular fibrillation during global ischemia and reperfusion: paradoxical changes in activation rate and wavefront complexity. Circ Arrhythm Electrophysiol (2011) 4(5):684-91. doi:10.1161/CIRCEP.110.961284

98. Kazbanov IV, Clayton RH, Nash MP, Bradley CP, Paterson DJ, Hayward MP, et al. Effect of global cardiac ischemia on human ventricular fibrillation: insights from a multi-scale mechanistic model of the human heart. PLoS Comput Biol (2014) 10(11):e1003891. doi:10.1371/journal.pcbi.1003891

99. Lown B. Sudden cardiac death: the major challenge confronting contemporary cardiology. Am J Cardiol (1979) 43(2):313-28. doi:10.1016/ S0002-9149(79)80021-1

100. Lown B. Sudden cardiac death: biobehavioral perspective. Circulation (1987) 76(1 Pt 2):I186-96.

101. Lown B, Temte JV, Reich P, Gaughan C, Regestein Q, Hal H. Basis for recurring ventricular fibrillation in the absence of coronary heart disease and its management. N Engl J Med (1976) 294(12):623-9. doi:10.1056/ NEJM197603182941201

102. Lown B, Verrier RL, Rabinowitz SH. Neural and psychologic mechanisms and the problem of sudden cardiac death. Am J Cardiol (1977) 39(6):890-902. doi:10.1016/S0002-9149(77)80044-1

103. Verrier RL, Hagestad EL, Lown B. Delayed myocardial ischemia induced by anger. Circulation (1987) 75(1):249-54. doi:10.1161/01.CIR.75.1.249

104. Skinner JE, Reed JC. Blockade of frontocortical-brain stem pathway prevents ventricular fibrillation of ischemic heart. Am JPhysiol (1981) 240(2):H156-63.

105. Corbalan R, Verrier R, Lown B. Psychological stress and ventricular arrhythmias during myocardial infarction in the conscious dog. Am J Cardiol (1974) 34(6):692-6. doi:10.1016/0002-9149(74)90159-3

106. Lown B, Verrier R, Corbalan R. Psychologic stress and threshold for repetitive ventricular response. Science (1973) 182(4114):834-6. doi:10.1126/ science.182.4114.834

107. Verrier RL, Lown B. Influence of neural activity on ventricular electrical instability during acute myocardial ischemia and infarction. In: Sandoe E, Julian DG, Bell JW, editors. Management of Ventricular Tachycardia-Role of Mexiletine. Amsterdam: Excerpta Medica (International Congress Series No. 458) (1978). p. 133-50.

108. Verrier RL, Lown B. Behavioral stress and cardiac arrhythmias. Annu Rev Physiol (1984) 46:155-76. doi:10.1146/annurev.ph.46.030184.001103

109. Verrier R, Lombardi F, Lown B, editors. Restraint of myocardial blood-flow during behavioral stress. Circulation. Dallas: American Heart Association (1982).

110. Adameova A, Abdellatif Y, Dhalla NS. Role of the excessive amounts of circulating catecholamines and glucocorticoids in stress-induced heart disease. Can J Physiol Pharmacol (2009) 87(7):493-514. doi:10.1139/y09-042

111. Gillis R. Neurotransmitters involved in the central nervous-system control of cardiovascular function. Dev Neurosci (1982) 15:41-53.

112. Segal SA, Jacob T, Gillis RA. Blockade of central nervous system GABAergic tone causes sympathetic-mediated increases in coronary vascular resistance in cats. Circ Res (1984) 55(3):404-15. doi:10.1161/01.RES.55.3.404

113. Pasyk S, Walton J, Pitt B, editors. Central opioid mediated coronary and systemic vasoconstriction in the conscious dog. Circulation. Dallas: American Heart Association (1981).

114. Kent KM, Smith ER, Redwood DR, Epstein SE. Electrical stability of acutely ischemic myocardium. Influences of heart rate and vagal stimulation. Circulation (1973) 47(2):291-8. doi:10.1161/01.CIR.47.2.291

115. DeSilva RA, Verrier RL, Lown B. The effects of psychological stress and vagal stimulation with morphine on vulnerability to ventricular fibrillation (VF) in the conscious dog. Am Heart J (1978) 95(2):197-203. doi:10.1016/0002-8703(78)90463-5

116. Meerson FZ, Ustinova EE, Manukhina EB. Prevention of cardiac arrhythmias by adaptation to hypoxia: regulatory mechanisms and cardiotropic effect. Biomed Biochim Acta (1989) 48(2-3):S83-8. 
117. Wu S, Wong MC, Chen M, Cho CH, Wong TM. Role of opioid receptors in cardioprotection of cold-restraint stress and morphine. J Biomed Sci (2004) 11(6):726-31. doi:10.1007/BF02254356

118. Havoundjian H, Paul SM, Skolnick P. Acute, stress-induced changes in the benzodiazepine/gamma-aminobutyric acid receptor complex are confined to the chloride ionophore. J Pharmacol Exp Ther (1986) 237(3):787-93.

119. Liberzon I, Krstov M, Young EA. Stress-restress: effects on ACTH and fast feedback. Psychoneuroendocrinology (1997) 22(6):443-53. doi:10.1016/ S0306-4530(97)00044-9

120. Purdy RH, Morrow AL, Moore PH Jr, Paul SM. Stress-induced elevations of gamma-aminobutyric acid type A receptor-active steroids in the rat brain. Proc Natl Acad Sci U S A (1991) 88(10):4553-7. doi:10.1073/pnas.88.10.4553

121. Schwartz RD, Wess MJ, Labarca R, Skolnick P, Paul SM. Acute stress enhances the activity of the GABA receptor-gated chloride ion channel in brain. Brain Res (1987) 411(1):151-5. doi:10.1016/0006-8993(87)90692-5

122. Miao YL, Guo WZ, Shi WZ, Fang WW, Liu Y, Liu J, et al. Midazolam ameliorates the behavior deficits of a rat posttraumatic stress disorder model through dual $18 \mathrm{kDa}$ translocator protein and central benzodiazepine receptor and neurosteroidogenesis. PLoS One (2014) 9(7):e101450. doi:10.1371/ journal.pone. 0101450

123. Resstel LB, Tavares RF, Lisboa SF, Joca SR, Correa FM, Guimaraes FS. 5-HT1A receptors are involved in the cannabidiol-induced attenuation of behavioural and cardiovascular responses to acute restraint stress in rats. Br J Pharmacol (2009) 156(1):181-8. doi:10.1111/j.1476-5381.2008.00046.x

124. Qian YZ, Shipley JB, Levasseur JE, Kukreja RC. Dissociation of heat shock proteins expression with ischemic tolerance by whole body hyperthermia in rat heart. J Mol Cell Cardiol (1998) 30(6):1163-72. doi:10.1006/ jmcc. 1998.0680

125. Taylor RP, Harris MB, Starnes JW. Acute exercise can improve cardioprotection without increasing heat shock protein content. Am J Physiol (1999) 276(3 Pt 2):H1098-102.

126. Hoshida S, Yamashita N, Otsu K, Hori M. Repeated physiologic stresses provide persistent cardioprotection against ischemia-reperfusion injury in rats. J Am Coll Cardiol (2002) 40(4):826-31. doi:10.1016/S0735-1097(02)02001-6

127. Joyeux M, Godin-Ribuot D, Patel A, Demenge P, Yellon DM, Ribuot C. Infarct size-reducing effect of heat stress and alphal adrenoceptors in rats. Br J Pharmacol (1998) 125(4):645-50. doi:10.1038/sj.bjp.0702137

128. Locke M, Tanguay RM, Klabunde RE, Ianuzzo CD. Enhanced postischemic myocardial recovery following exercise induction of HSP 72. Am J Physiol (1995) 269(1 Pt 2):H320-5.

129. Murry CE, Jennings RB, Reimer KA. Preconditioning with ischemia: a delay of lethal cell injury in ischemic myocardium. Circulation (1986) 74(5):1124-36. doi:10.1161/01.CIR.74.5.1124

130. Das M, Das DK. Molecular mechanism of preconditioning. IUBMB Life (2008) 60(4):199-203. doi:10.1002/iub.31

131. Wang GY, Wu S, Pei JM, Yu XC, Wong TM. Kappa- but not delta-opioid receptors mediate effects of ischemic preconditioning on both infarct and arrhythmia in rats. Am J Physiol Heart Circ Physiol (2001) 280(1):H384-91.

132. Scheuer DA, Mifflin SW. Repeated intermittent stress exacerbates myocardial ischemia-reperfusion injury. Am J Physiol (1998) 274(2 Pt 2):R470-5.

133. Ravingerova T, Bernatova I, Matejikova J, Ledvenyiova V, Nemcekova M, Pechanova $\mathrm{O}$, et al. Impaired cardiac ischemic tolerance in spontaneously hypertensive rats is attenuated by adaptation to chronic and acute stress. Exp Clin Cardiol (2011) 16(3):e23-9.

134. Ledvenyiova-Farkasova V, Bernatova I, Balis P, Puzserova A, Bartekova M, GablovskyI, etal.Effect of crowding stresson toleranceto ischemia-reperfusion injury in young male and female hypertensive rats: molecular mechanisms. Can J Physiol Pharmacol (2015) 93(9):793-802. doi:10.1139/cjpp-2015-0026

135. Rorabaugh BR, Krivenko A, Eisenmann ED, Bui AD, Seeley S, Fry ME, et al. Sex-dependent effects of chronic psychosocial stress on myocardial sensitivity to ischemic injury. Stress (2015) 18(6):645-53. doi:10.3109/1025 3890.2015.1087505

136. Zoladz PR, Conrad CD, Fleshner M, Diamond DM. Acute episodes of predator exposure in conjunction with chronic social instability as an animal model of post-traumatic stress disorder. Stress (2008) 11(4):259-81. doi:10.1080/10253890701768613

137. Dhabhar FS, Malarkey WB, Neri E, McEwen BS. Stress-induced redistribution of immune cells - from barracks to boulevards to battlefields: a tale of three hormones - Curt Richter Award winner. Psychoneuroendocrinology (2012) 37(9):1345-68. doi:10.1016/j.psyneuen.2012.05.008

138. Viswanathan K, Dhabhar FS. Stress-induced enhancement of leukocyte trafficking into sites of surgery or immune activation. Proc Natl Acad Sci U S A (2005) 102(16):5808-13. doi:10.1073/pnas.0501650102

139. Huang M, Pang X, Letourneau R, Boucher W, Theoharides TC. Acute stress induces cardiac mast cell activation and histamine release, effects that are increased in Apolipoprotein E knockout mice. Cardiovasc Res (2002) 55(1):150-60. doi:10.1016/S0008-6363(02)00336-X

140. Meerson F, Ustinova E. Effect of long-term and short-term stress actions on the heart resistance to anoxia. Bulleten Eksperimentalnoyi Biologii i Meditziny (1983) 1:21-3.

141. Kiecolt-Glaser JK, Dura JR, Speicher CE, Trask OJ, Glaser R. Spousal caregivers of dementia victims: longitudinal changes in immunity and health. Psychosom Med (1991) 53(4):345-62. doi:10.1097/00006842-199107000-00001

142. Vrshek-Schallhorn S, Stroud CB, Mineka S, Hammen C, Zinbarg RE, Wolitzky-Taylor K, et al. Chronic and episodic interpersonal stress as statistically unique predictors of depression in two samples of emerging adults. J Abnorm Psychol (2015) 124(4):918-32. doi:10.1037/abn0000088

143. Davey A, Sharma P, Davey S, Shukla A, Srivastava K, Vyas S. Are the adverse psychiatric outcomes reflection of occupational stress among nurses: an exploratory study. Asian J Med Sci (2015) 7(1):96-100. doi:10.3126/ajms. v7i1.12869

144. Seib C, Whiteside E, Humphreys J, Lee K, Thomas P, Chopin L, et al. A longitudinal study of the impact of chronic psychological stress on health-related quality of life and clinical biomarkers: protocol for the Australian Healthy Aging of Women Study. BMC Public Health (2014) 14:9. doi:10.1186/1471-2458-14-9

145. Sans S, Kesteloot H, Kromhout D. The burden of cardiovascular diseases mortality in Europe. Task Force of the European Society of Cardiology on Cardiovascular Mortality and Morbidity Statistics in Europe. Eur Heart $J$ (1997) 18(8):1231-48. doi:10.1093/oxfordjournals.eurheartj.a015434

146. Rosengren A, Subramanian SV, Islam S, Chow CK, Avezum A, Kazmi K, et al. Education and risk for acute myocardial infarction in 52 high, middle and low-income countries: INTERHEART case-control study. Heart (2009) 95(24):2014-22. doi:10.1136/hrt.2009.182436

147. Ferrie JE, Kivimaki M, Shipley MJ, Davey Smith G, Virtanen M. Job insecurity and incident coronary heart disease: the Whitehall II prospective cohort study. Atherosclerosis (2013) 227(1):178-81. doi:10.1016/j. atherosclerosis.2012.12.027

148. Netterstrom B, Kristensen TS, Jensen G, Schnor P. Is the demand-control model still a useful tool to assess work-related psychosocial risk for ischemic heart disease? Results from 14 year follow up in the Copenhagen City Heart study. Int J Occup Med Environ Health (2010) 23(3):217-24. doi:10.2478/ v10001-010-0031-6

149. Toren K, Schioler L, Giang WK, Novak M, Soderberg M, Rosengren A. A longitudinal general population-based study of job strain and risk for coronary heart disease and stroke in Swedish men. BMJ Open (2014) 4(3):e004355. doi:10.1136/bmjopen-2013-004355

150. Kivimaki M, Ferrie JE, Brunner E, Head J, Shipley MJ, Vahtera J, et al. Justice at work and reduced risk of coronary heart disease among employees: the Whitehall II study. Arch Intern Med (2005) 165(19):2245-51. doi:10.1001/ archinte.165.19.2245

151. Kivimaki M, Jokela M, Nyberg ST, Singh-Manoux A, Fransson EI, Alfredsson L, et al. Long working hours and risk of coronary heart disease and stroke: a systematic review and meta-analysis of published and unpublished data for 603,838 individuals. Lancet (2015) 386(10005):1739-46. doi:10.1016/S0140-6736(15)60295-1

152. Sparen P, Vagero D, Shestov DB, Plavinskaja S, Parfenova N, Hoptiar V, et al. Long term mortality after severe starvation during the siege of Leningrad: prospective cohort study. BMJ (2004) 328(7430):11. doi:10.1136/ bmj.37942.603970.9A

153. Grippo AJ, Beltz TG, Johnson AK. Behavioral and cardiovascular changes in the chronic mild stress model of depression. Physiol Behav (2003) 78(4-5):703-10. doi:10.1016/S0031-9384(03)00050-7

154. Carney RM, Freedland KE. Depression, mortality, and medical morbidity in patients with coronary heart disease. Biol Psychiatry (2003) 54(3):241-7. doi:10.1016/S0006-3223(03)00111-2 
155. Wulsin LR, Singal BM. Do depressive symptoms increase the risk for the onset of coronary disease? A systematic quantitative review. Psychosom Med (2003) 65(2):201-10. doi:10.1097/01.PSY.0000058371.50240.E3

156. Edmondson D, Cohen BE. Posttraumatic stress disorder and cardiovascular disease. Prog Cardiovasc Dis (2013) 55(6):548-56. doi:10.1016/j.pcad.2013 .03 .004

157. Edmondson D, Kronish IM, Shaffer JA, Falzon L, Burg MM. Posttraumatic stress disorder and risk for coronary heart disease: a meta-analytic review. Am Heart J (2013) 166(5):806-14. doi:10.1016/j.ahj.2013.07.031

158. Vaccarino V, Goldberg J, Rooks C, Shah AJ, Veledar E, Faber TL, et al. Posttraumatic stress disorder and incidence of coronary heart disease: a twin study. J Am Coll Cardiol (2013) 62(11):970-8. doi:10.1016/j.jacc.2013.04.085

159. Kaplan JR, Manuck SB, Clarkson TB, Lusso FM, Taub DM, Miller EW. Social stress and atherosclerosis in normocholesterolemic monkeys. Science (1983) 220(4598):733-5. doi:10.1126/science.6836311

160. Ratcliffe HL, Luginbuhl H, Schnarr WR, Chacko K. Coronary arteriosclerosis in swine: evidence of a relation to behavior. J Comp Physiol Psychol (1969) 68(3):385-92. doi:10.1037/h0027520

161. Liang B, Verrier RL, Melman J, Lown B. Correlation between circulating catecholamine levels and ventricular vulnerability during psychological stress in conscious dogs. Exp Biol Med (1979) 161(3):266-9. doi:10.3181/00379727-161-40533

162. Rosenfeld J, Rosen MR, Hoffman BF. Pharmacologic and behavioral effects on arrhythmias that immediately follow abrupt coronary occlusion: a canine model of sudden coronary death. Am J Cardiol (1978) 41(6):1075-82. doi:10.1016/0002-9149(78)90860-3

163. Grippo AJ, Johnson AK. Biological mechanisms in the relationship between depression and heart disease. Neurosci Biobehav Rev (2002) 26(8):941-62. doi:10.1016/S0149-7634(03)00003-4

164. Grippo AJ, Francis J, Beltz TG, Felder RB, Johnson AK. Neuroendocrine and cytokine profile of chronic mild stress-induced anhedonia. Physiol Behav (2005) 84(5):697-706. doi:10.1016/j.physbeh.2005.02.011

165. Grippo AJ, Beltz TG, Weiss RM, Johnson AK. The effects of chronic fluoxetine treatment on chronic mild stress-induced cardiovascular changes and anhedonia. Biol Psychiatry (2006) 59(4):309-16. doi:10.1016/j. biopsych.2005.07.010

166. Sgoifo A, Carnevali L, Grippo AJ. The socially stressed heart. Insights from studies in rodents. Neurosci Biobehav Rev (2014) 39:51-60. doi:10.1016/j. neubiorev.2013.12.005

167. Wood SK. Cardiac autonomic imbalance by social stress in rodents: understanding putative biomarkers. Front Psychol (2014) 5:950. doi:10.3389/ fpsyg.2014.00950

168. Mancardi D, Tullio F, Crisafulli A, Rastaldo R, Folino A, Penna C, et al. Omega 3 has a beneficial effect on ischemia/reperfusion injury, but cannot reverse the effect of stressful forced exercise. Nutr Metab Cardiovasc Dis (2009) 19(1):20-6. doi:10.1016/j.numecd.2008.01.004

169. Kolar F, Jezkova J, Balkova P, Breh J, Neckar J, Novak F, et al. Role of oxidative stress in PKC-delta upregulation and cardioprotection induced by chronic intermittent hypoxia. Am J Physiol Heart Circ Physiol (2007) 292(1):H224-30. doi:10.1152/ajpheart.00689.2006

170. Nalivaiko E. Animal models of psychogenic cardiovascular disorders: what we can learn from them and what we cannot. Clin Exp Pharmacol Physiol (2011) 38(2):115-25. doi:10.1111/j.1440-1681.2010.05465.x

171. Jia M, Smerin SE, Zhang L, Xing G, Li X, Benedek D, et al. Corticosterone mitigates the stress response in an animal model of PTSD. J Psychiatr Res (2015) 60:29-39. doi:10.1016/j.jpsychires.2014.09.020

172. Chourbaji S, Zacher C, Sanchis-Segura C, Dormann C, Vollmayr B, Gass P. Learned helplessness: validity and reliability of depressive-like states in mice. Brain Res Brain Res Protoc (2005) 16(1-3):70-8. doi:10.1016/j.brainresprot. 2005.09.002

173. Li B, Yang CJ, Yue N, Liu Y, Yu J, Wang YQ, et al. Clomipramine reverses hypoalgesia/hypoesthesia and improved depressive-like behaviors induced by inescapable shock in rats. Neurosci Lett (2013) 541:227-32. doi:10.1016/j. neulet.2013.01.055

174. Armario A, Ortiz R, Balasch J. Effect of crowding on some physiological and behavioral variables in adult male rats. Physiol Behav (1984) 32(1):35-7. doi:10.1016/0031-9384(84)90066-0

175. Bugajski J. Social stress adapts signaling pathways involved in stimulation of the hypothalamic-pituitary-adrenal axis. JPhysiol Pharmacol (1999) 50(3):367-79.
176. Bugajski J, Borycz J, Glod R, Bugajski AJ. Crowding stress impairs the pituitary-adrenocortical responsiveness to the vasopressin but not corticotropin-releasing hormone stimulation. Brain Res (1995) 681(1-2):223-8. doi:10.1016/0006-8993(95)00297-4

177. Sgoifo A, Koolhaas J, De Boer S, Musso E, Stilli D, Buwalda B, et al. Social stress, autonomic neural activation, and cardiac activity in rats. Neurosci Biobehav Rev (1999) 23(7):915-23. doi:10.1016/S0149-7634(99)00025-1

178. Vicario M, Alonso C, Guilarte M, Serra J, Martinez C, Gonzalez-Castro AM, et al. Chronic psychosocial stress induces reversible mitochondrial damage and corticotropin-releasing factor receptor type-1 upregulation in the rat intestine and IBS-like gut dysfunction. Psychoneuroendocrinology (2012) 37(1):65-77. doi:10.1016/j.psyneuen.2011.05.005

179. Zoladz PR, Fleshner M, Diamond DM. Psychosocial animal model of PTSD produces a long-lasting traumatic memory, an increase in general anxiety and PTSD-like glucocorticoid abnormalities. Psychoneuroendocrinology (2012) 37(9):1531-45. doi:10.1016/j.psyneuen.2012.02.007

180. Zoladz PR, Fleshner M, Diamond DM. Differential effectiveness of tianeptine, clonidine and amitriptyline in blocking traumatic memory expression, anxiety and hypertension in an animal model of PTSD. Prog Neuropsychopharmacol Biol Psychiatry (2013) 44:1-16. doi:10.1016/j.pnpbp.2013.01.001

181. Zoladz PR, Park CR, Fleshner M, Diamond DM. Psychosocial predator-based animal model of PTSD produces physiological and behavioral sequelae and a traumatic memory four months following stress onset. Physiol Behav (2015) 147:183-92. doi:10.1016/j.physbeh.2015.04.032

182. Wilson CB, McLaughlin LD, Nair A, Ebenezer PJ, Dange R, Francis J. Inflammation and oxidative stress are elevated in the brain, blood, and adrenal glands during the progression of post-traumatic stress disorder in a predator exposure animal model. PLoS One (2013) 8(10):e76146. doi:10.1371/journal. pone. 0076146

183. Wilson CB, Ebenezer PJ, McLaughlin LD, Francis J. Predator exposure/psychosocial stress animal model of post-traumatic stress disorder modulates neurotransmitters in the rat hippocampus and prefrontal cortex. PLoS One (2014) 9(2):e89104. doi:10.1371/journal.pone.0089104

184. Rorabaugh BR, Ross SA, Gaivin RJ, Papay RS, McCune DF, Simpson PC, et al. Alphala- but not alpha1B-adrenergic receptors precondition the ischemic heart by a staurosporine-sensitive, chelerythrine-insensitive mechanism. Cardiovasc Res (2005) 65(2):436-45. doi:10.1016/j.cardiores.2004.10.009

185. Banerjee A, Locke-Winter C, Rogers KB, Mitchell MB, Brew EC, Cairns $\mathrm{CB}$, et al. Preconditioning against myocardial dysfunction after ischemia and reperfusion by an alpha 1-adrenergic mechanism. Circ Res (1993) 73(4):656-70. doi:10.1161/01.RES.73.4.656

186. Davel AP, Kawamoto EM, Scavone C, Vassallo DV, Rossoni LV. Changes in vascular reactivity following administration of isoproterenol for 1 week: a role for endothelial modulation. Br J Pharmacol (2006) 148(5):629-39. doi:10.1038/sj.bjp.0706749

187. Kim HK, Park WS, Warda M, Park SY, Ko EA, Kim MH, et al. Beta adrenergic overstimulation impaired vascular contractility via actin-cytoskeleton disorganization in rabbit cerebral artery. PLoS One (2012) 7(8):e43884. doi:10.1371/journal.pone.0043884

188. Pye MP, Cobbe SM. Mechanisms of ventricular arrhythmias in cardiac failure and hypertrophy. Cardiovasc Res (1992) 26(8):740-50. doi:10.1093/ $\mathrm{cvr} / 26.8 .740$

189. Lochner A, Genade S, Tromp E, Podzuweit T, Moolman JA. Ischemic preconditioning and the beta-adrenergic signal transduction pathway. Circulation (1999) 100(9):958-66. doi:10.1161/01.CIR.100.9.958

190. Suematsu Y, Anttila V, Takamoto S, del Nido P. Cardioprotection afforded by ischemic preconditioning interferes with chronic betablocker treatment. Scand Cardiovasc J (2004) 38(5):293-9. doi:10.1080/ 14017430410021507

Conflict of Interest Statement: The authors declare that the research was conducted in the absence of any commercial or financial relationships that could be construed as a potential conflict of interest.

Copyright $\odot 2016$ Eisenmann, Rorabaugh and Zoladz. This is an open-access article distributed under the terms of the Creative Commons Attribution License (CC BY). The use, distribution or reproduction in other forums is permitted, provided the original author(s) or licensor are credited and that the original publication in this journal is cited, in accordance with accepted academic practice. No use, distribution or reproduction is permitted which does not comply with these terms. 